\title{
Working
}

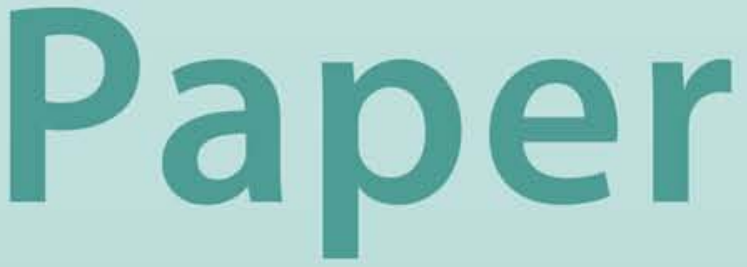


Regional Trade Integration and WTO

Accession: Which Is the Right

Sequencing? An Application to the CIS

Patrizia Tumbarello 


\title{
IMF Working Paper
}

Policy Development and Review Department

\section{Regional Trade Integration and WTO Accession: Which Is the Right Sequencing? An Application to the CIS}

\author{
Prepared by Patrizia Tumbarello
}

Authorized for distribution by Hans Peter Lankes

May 2005

\begin{abstract}
This Working Paper should not be reported as representing the views of the IMF. The views expressed in this Working Paper are those of the author(s) and do not necessarily represent those of the IMF or IMF policy. Working Papers describe research in progress by the author(s) and are published to elicit comments and to further debate.

This paper analyzes the appropriate sequencing between accession to the World Trade Organization (WTO) and the implementation of the Eurasian Economic Community (EAEC) customs union and whether the latter facilitates or delays WTO accession for some member countries of the Commonwealth of Independent States (CIS). If EAEC members pursue a coordinated approach toward WTO accession, this may cause delays that benefit some countries at the expense of others. The paper simulates the welfare effects resulting from the two sequencing alternatives (customs union and WTO or the reverse). The results show that, from a consumer surplus standpoint, it would be preferable to join the WTO ahead of the EAEC customs union. This paper does not attempt to assess the welfare implications of joining the EAEC as a political and economic entity, but only the welfare implications resulting from the implementation of the EAEC customs union.

JEL Classification Numbers: F13, F15, F47, P33

Keywords: Regional trade integration; CIS; WTO

Author(s) E-Mail Address: ptumbarello@imf.org

\footnotetext{
${ }^{1}$ The author wishes to thank Veronica Bacalu, Emanuele Baldacci, Nur Calika, Katrin Elborgh-Woytek, Jean-Jacques Hallaert, Alvin Hilaire, Etibar Jafarov, Natalia Koliadina, Hans Peter Lankes, Yaroslav Lissovolik, Brad McDonald, Costas Michalopoulos, Lynge Nielsen, Marcelo Olarreaga, Clint Shiells, David Tarr, Jerome Vandenbussche, and John Wakeman-Linn for their helpful comments, and Dustin Smith for his valuable input in elaborating EAEC countries' tariff schedules. Mary Jo Marquez provided excellent administrative support. This paper was prepared in association with the work program of the Trade Policy Division/PDR.
} 
I. Introduction

II. Sequencing Between WTO Accession and Customs Union Membership:

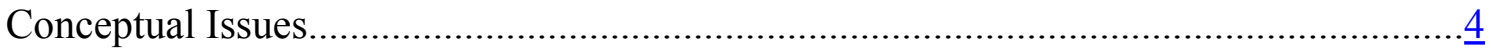

III. Regional Trade Integration in the CIS ..............................................................

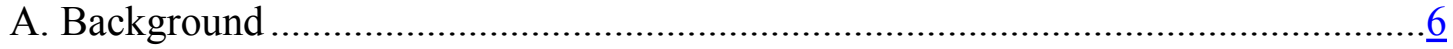

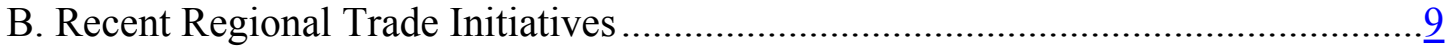

C. Current Status of the CIS Trade Regimes ..................................................

D. Comparison of EAEC Members' Tariff Structure with the EAEC Common

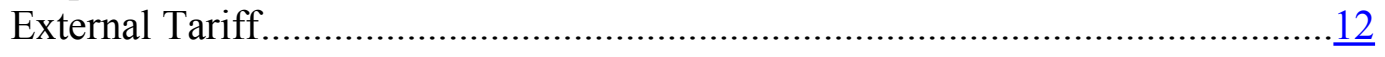

IV. Estimation of the Welfare Effect of EAEC Customs Union Membership ......................12

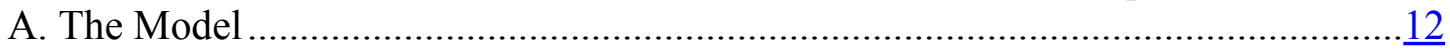

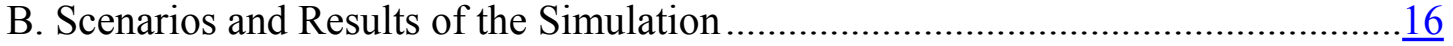

V. WTO Accession and the EAEC Customs Union: Negotiation Issues and

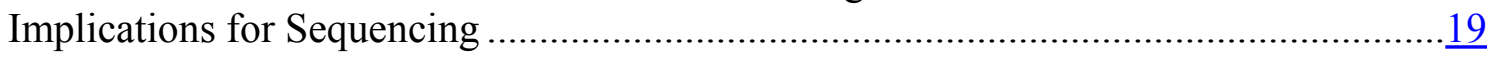

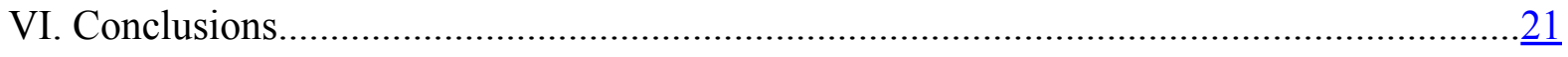

Tables

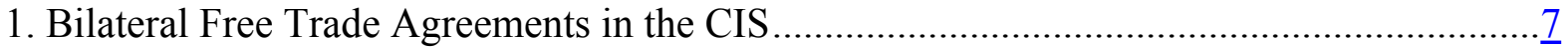

2. Selected Trade Regime Indicators in the CIS, 2003 .....................................................11

3. EAEC Members' Current Tariff Structure Compared with the EAEC Tariff Rates.............13

4. Scenario 1: Impact on Welfare of EAEC Customs Union Implementation Prior to

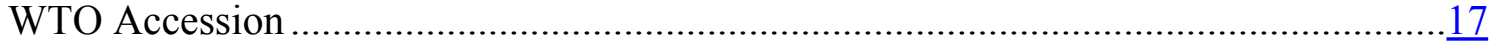

5. Scenario 2: Impact on Welfare of EAEC Customs Union Implementation Following

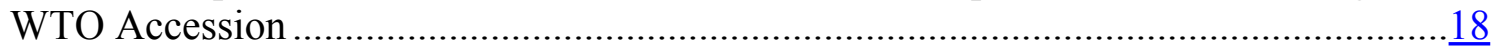

6. WTO Accession Status of the CIS ..................................................................... $\underline{20}$

Box

1. WTO and Regional Trade Integration. What Does the Theory of Incentives Say? .............. $\underline{8}$

Annex

Regional Cooperation Agreements and Initiatives in the CIS

References 


\section{INTRODUCTION}

Regional trade agreements continue to proliferate despite being economically inferior from a global perspective to nondiscriminatory trade liberalization on a most-favored-nation (MFN) basis. Multilateral liberalization and regional integration will continue to coexist in the future. $^{2}$

This paper analyzes the issues involved in determining the appropriate sequencing between World Trade Organization (WTO) accession (multilateral liberalization) and the implementation of customs unions, focusing on the Commonwealth of Independent States (CIS). ${ }^{3}$ Because customs unions are not inconsistent with the multilateral framework-in that the $\mathrm{WTO}^{4}$ allows members to participate in preferential trade agreements that meet certain standards - the appropriate sequencing between the two options is an important consideration.

This focus on the CIS is motivated by the new momentum in the CIS of regional cooperation initiatives, with customs unions established first: the Eurasian Economic Community (EAEC)-a political and economic union between Belarus, Kazakhstan, the Kyrgyz Republic, the Russian Federation, and Tajikistan, and, more recently, the proposal for a Common Economic Space (CES) between the Russian Federation, Belarus, Kazakhstan, and Ukraine. EAEC and prospective CES members have expressed a strong commitment to implementing these customs unions as a first step toward deeper integration, and they have already undertaken actions to this end. Although EAEC implementation is still far from complete, its members have recently increased their efforts toward implementing common EAEC tariff rates, while at the same time, several members are seeking accession to the WTO.

The paper uses the consumer welfare of individual country members as a benchmark to assess the desirability of each sequencing path-as opposed to the consumer welfare of the EAEC as a whole - and focuses on two related questions:

- $\quad$ Should EAEC members focus trade integration efforts first on multilateral liberalization through the WTO rather than on a customs union?

\footnotetext{
${ }^{2}$ As of end-2003, 193 regional trade agreements had been notified to the WTO and were in force. Another 70 were estimated to be operational but not yet notified to the WTO (WTO, 2004, and WTO Secretariat).

${ }^{3}$ The CIS comprises Armenia, Azerbaijan, Belarus, Georgia, Kazakhstan, the Kyrgyz Republic, Moldova, the Russian Federation, Tajikistan, Turkmenistan, Ukraine, and Uzbekistan.

${ }^{4}$ This is specified in Article XXIV of the GATT/WTO and Article V of the GATS, subject to several requirements: mainly, that duties and other restrictive regulation of commerce should be eliminated on "substantially all trade" between the members. Also, the agreement should include a plan and a schedule for the formation of a free trade area, or a custom union, within 10 years.
} 
- If the customs union is pursued first or in parallel to WTO accession, would custom union membership complicate or delay WTO accession?

Although the WTO does not envisage negotiations at a regional level, the EAEC countries that are not yet members of the WTO have begun a coordinated approach toward the WTO by seeking common terms of accession in order to reconcile future WTO commitments with EAEC commitments.

The paper provides a simple partial equilibrium model to estimate the welfare impact of the two sequencing alternatives using commodity-level data in two scenarios. The first scenario simulates the impact on welfare of adopting the EAEC common external tariff prior to WTO accession, while the second scenario simulates the impact on welfare of adopting the EAEC common external tariff after joining the WTO. The results of the simulations show that, from a consumer standpoint, it would be preferable to join the WTO before implementing the customs union envisaged by the EAEC should the latter imply an increase in the rate of protection for its members.

Section II reviews the analytical issues of sequencing between WTO membership and customs unions. Section III focuses on regional trade integration in the CIS. It describes the EAEC and how its current tariff structure compares to the current tariff structures of its members. Section IV presents a partial equilibrium model to simulate the welfare effects resulting from implementation of the EAEC customs union prior to WTO accession, as well as the reverse scenario. Section $\mathrm{V}$ spells out the policy issues related to the different sequencing paths for EAEC members, while Section VI presents the conclusions of the paper.

\section{Sequencing Between WTO ACCESSION AND Customs UNION MEMBERSHIP: CONCEPTUAL ISSUES}

The welfare effects of the two sequencing paths can vary considerably. Even though a customs union may not limit the scope for future multilateral liberalization, it can further delay the WTO accession process. In some cases both the pursuit of a customs union and WTO membership may proceed simultaneously because full implementation of a customs union may be phased. Parallel accession to the WTO and the joining of a customs union may be treated as if customs union membership precedes WTO accession. ${ }^{5}$ This is because customs union commitments, although not entirely defined or implemented, are already affecting the WTO accession negotiations.

A powerful argument in favor of multilateral liberalization before customs union participation is that regionalism can act as a stumbling block toward the process of further liberalization. Political economy considerations suggest that inefficient firms will lobby

\footnotetext{
${ }^{5}$ This is the case of the EAEC.
} 
against future removal of the preferential rates that protect their interests and will exert political pressure to avoid multilateral liberalization (Krueger, 1995, and Krishna, 1998).

Joining the WTO prior to entering a customs union can induce competitive accession to the WTO in the region. This is beneficial especially for a small open economy. In fact, a country joining the WTO before its regional neighbors will be able to extract concessions from members within the WTO framework that would be impossible to obtain bilaterally or in a regional trade agreement by influencing the WTO terms of accession of the other regional applicant countries. ${ }^{6}$

The choice of forming a customs union first and then acceding to the WTO could increase the overall level of trade protection of customs union members compared to their level of protection prior to the customs union. The larger the customs union the more the collective monopoly power it has in commanding a high level of protection (Krugman, 1991 and 1993). ${ }^{7}$ The incentive to protect is particularly strong if there is a country with greater bargaining power within the region and higher external tariff rates. The reason is that, in the case of heterogeneous countries, the higher external tariff of the dominant country is likely to prevail as a Common External Tariff (CET) for the group. In this case, implementation of the customs union implies that the more liberal countries will eventually converge toward the higher rates. This may produce a different degree of trade diversion across countries causing negative welfare effects. In particular, some domestic producers could gain at the expense of other countries' consumers.

Customs union membership can delay the WTO accession process: finding a mutually acceptable position during the multilateral negotiations within the WTO might be more difficult, or at least more time consuming, because of the need to reconcile the interests of several constituencies. ${ }^{8}$ This delay is likely to be particularly costly to small open economies that have proportionally more to gain from trade integration and more rapid accession, whereas some of the larger economies in the customs union might be more concerned with the terms than with the speed of the process.

But forming customs unions first can also bring benefits to their members. By entering first into a regional agreement, a country may increase its bargaining power in multilateral

\footnotetext{
${ }^{6}$ Bhagwati (1993) and Panagariya (1995) argue that large countries may use their bargaining power in regional arrangements to obtain distorting concessions from small countries that they might not obtain in more balanced multilateral negotiations.

${ }^{7}$ Large players tend to impose higher tariffs than small players, i.e., the temptation of the former to protect is higher because they have more monopoly power to exploit.

${ }^{8}$ See Schiff and Winters (2003). Also, Ludema (1996) shows that customs unions might be effective bargainers in multilateral negotiations because of the customs union commitment to a CET unless there is heterogeneity among partners.
} 
negotiations by having a common (regional) position toward sensitive issues (e.g., textile and agriculture), where developed countries still maintain a protectionist stance, although it is not obvious, a priori, that the outcome would reflect the preferences of custom unions' smaller members. Moreover, some authors have argued that by entering into multilateral negotiations as a region, rather than a country, small states might face lower fixed costs of negotiation. ${ }^{9}$ Coordination among countries in a customs union is also meant to prevent custom union members from undercutting each other during negotiations. The prevention of undercutting, however, would certainly imply a high degree of protection with negative effects on consumer welfare.

If the customs union precedes the multilateral liberalization, one relevant issue is how the WTO negotiations will be handled, at the individual level or de facto at the regional level. In the latter case, the question is which entity will lead, even informally, the negotiations. A cooperative approach to WTO accession can have important welfare implications, depending on which interests prevail. A dominant member may unofficially lead the negotiations for all customs union members, and the benefits of the terms negotiated are likely to vary across countries. ${ }^{10}$

An additional sequencing-related issue may occur if at least one of the customs union members is already a WTO member. If the other countries in the customs union have external tariffs similar to those of the WTO member, there is no problem for the latter to reconcile its WTO commitments with the CET. Moreover, in this case the overall level of trade protection among member countries of the customs union will not increase. If some customs union countries are more protectionist than the WTO member, however, not only could the overall level of protection increase but the WTO member may also face inconsistencies between its WTO and customs union commitments. In the latter case, other WTO members could "litigate," in principle. If the CET were not to be higher than the maximum tariff bindings negotiated by the WTO member for each tariff line, there would be no inconsistency between WTO and customs union commitments.

\section{REgIONAL TRADE INTEGRATION IN THE CIS}

\section{A. Background}

Since the breakup of the Soviet Union, the CIS countries have signed a large number of bilateral and regional trade agreements with each other, mainly in the first half of the 1990s (Table 1 and Annex 1). The proliferation of preferential trade agreements among the CIS countries during this period can be explained by an attempt to resuscitate previous linkages after the collapse of the Soviet Union. Preferential trade agreements were also

\footnotetext{
${ }^{9}$ See Andriamananjara and Schiff (2001).

${ }^{10}$ See Schiff and Winters (2003).
} 
Table 1. Bilateral Free Trade Agreements in the CIS

\begin{tabular}{|c|c|c|c|c|c|c|c|c|c|c|c|c|}
\hline & Armenia & Azerbaijan & Belarus & Georgia & Kazakhstan & Kyrgyz Rep. & Moldova & Russia & Tajikistan & Turkmenistan & Ukraine & Uzbekistan \\
\hline Armenia & $=$ & & & 1998 & 2001 & 1994 & 1993 & 1993 & & 1996 & & \\
\hline Azerbaijan & & $=$ & & 1996 & 1997 & & 1995 & 1992 & & 1996 & 1995 & 1996 \\
\hline Belarus & & & $=$ & & & & 1993 & 1996 & 1998 & & 1996 & 1993 \\
\hline Georgia & 1995 & 1998 & & $=$ & 1999 & & 1998 & 1994 & & 1996 & 1996 & 1995 \\
\hline Kazakhstan & & 1997 & 2001 & 1999 & $=$ & 1995 & 1995 & 1992 & & & & 1997 \\
\hline Kyrgyz Republic & 1994 & & & & 1995 & $=$ & 1995 & 1993 & & & 1998 & 1998 \\
\hline Moldova & 1993 & 1995 & 1993 & 1998 & 1995 & 1995 & $=$ & 1993 & & 1993 & 1995 & 1995 \\
\hline Russia & 1993 & 1992 & 1996 & 1994 & 1992 & 1993 & 1993 & $=$ & & & 1993 & 1992 \\
\hline Turkmenistan & 1996 & 1996 & & 1996 & & & 1993 & & & $=$ & & 1996 \\
\hline Ukraine & & 1995 & 1996 & 1996 & & 1998 & 1995 & 1993 & & & $=$ & 1994 \\
\hline Uzbekistan & & 1996 & 1993 & 1995 & 1997 & 1998 & 1995 & 1992 & 1996 & 1996 & 1994 & $=$ \\
\hline
\end{tabular}

Sources: Country authorities; and the WTO. 
perceived as a means by which to secure market access for goods within the CIS when market institutions, payments arrangements, and exchange rate convertibility were not yet functioning, and barter arrangements were still an important component of regional trade.

Despite their proliferation, in the past many CIS preferential trade agreements remained agreements on paper only. There are several reasons for this. First, the coverage is limited and unclear, which made the agreements either ineffective or irrelevant. Sometimes the most sensitive goods were excluded (e.g., gas and oil for Kazakhstan and the Russian Federation). Exemptions and exceptions were not harmonized across countries and were usually granted on an ad hoc basis, which introduces uncertainties in their application. Second, because these arrangements provide a mechanism to allocate rents, there has been a rise in conflicts of interests, trade disputes, and retaliation, delaying or blocking the implementation of some agreements. Third, the costs of enforcing rules of origin are often higher than the benefits associated with a preferential tariff regime. Therefore, importers often forgo claiming the preferential rates. Fourth, because regional institutions were absent in the past, the regional trade agreements had to be self-enforcing, which weakened their implementation (Box 1). ${ }^{11}$ Finally, the lack of harmonization in levying the value-added tax (VAT) in the past has resulted in numerous trade disputes and provoked suspension of the agreements on particular issues.

\section{Box 1. WTO and Regional Trade Integration. What Does the Theory of Incentives Say?}

To date, the CIS has not been able to agree upon an institutional mechanism that would enforce contracts between trading parties, which has diminished the effectiveness of these agreements. Much of this failure reflects the heterogeneity of the region in terms of different interests, bargaining power, and per capita income.

Both the WTO and regional trade agreements provide mechanisms to encourage cooperative behavior that prevents tariff wars. However, while the WTO can impose penalties within the framework of the international trading system on parties that deviate from the system, regional trade institutions are generally absent.

Therefore, it has been hard to enforce trade agreements at the regional level.

Against this background, the first question is whether a regional cooperative solution in the CIS can ever ensure a stable equilibrium. This would be possible, as long as all parties, driven by reputation concerns, were willing to cooperate. But suppose that one party decides to deviate from its equilibrium cooperative strategy so that all parties find themselves in an out-of-equilibrium outcome. If the deviating party proposes a renegotiation that all parties are willing to accept, the cooperative equilibrium will be destroyed. But is such an outcome likely to arise?

Assuming that a country with a prevailing position in the region also has a high level of bargaining power in the ensuing renegotiation, its incentives to deviate from its initial cooperative strategy will be high. This contrasts with small countries that are more likely to abide by their cooperative strategy, driven by the fear of being severely punished if they follow any deviating behavior. This asymmetry may induce the collapse of a mutually beneficial regional trade agreement. A solution would be to include this anticipated renegotiation game in the initial regional agreement so as to make it incentive compatible for all its members. An incentive-compatible regional agreement (mechanism) is hard to construct, however, because of the dominance of one player and its large bargaining power in the event of an ex post renegotiation.

\footnotetext{
${ }^{11}$ A recent exception is the EAEC, which has created regional institutions (see below) to regulate its implementation.
} 


\section{B. Recent Regional Trade Initiatives}

Despite past difficulties, some CIS countries have recently expressed renewed interest in pursuing regional trade integration, in particular in establishing customs unions as a first step toward deeper integration. The most recent initiatives include the implementation of the EAEC and a draft agreement to create a CES.

\section{The Eurasian Economic Community}

The EAEC agreement was signed in October 2000 between Belarus, Kazakhstan, the Kyrgyz Republic, the Russian Federation, and Tajikistan, and entered into force in May 2001. There are also three observers: Armenia, Moldova, and Ukraine. The agreement envisages the implementation of a customs union and, eventually, of a common economic area, implying a deeper economic integration and cooperation beyond the harmonization of external tariff rates. The EAEC supersedes the CIS customs union of the 1990s. ${ }^{12}$

The agreement on the CET, which was signed in February 2000, envisaged that the CET would consist of tariff lines that were common to Belarus, Kazakhstan, and Russia at that time but subject to further amendments, with the remaining tariff lines to be set at a later stage. The agreement also envisaged that the CET would be finalized and implemented in stages over a period of five years from the date of entry into force of the agreement, to be prolonged if necessary by mutual agreement of the parties. ${ }^{13}$ The current EAEC tariff schedule covers only 6,156 tariff lines out of the 11,086 identified in the EAEC classification system. The remaining tariffs are not bound yet and are set independently by each member.

In order to further harmonize external tariff rates, the CET agreement foresees that each member compile two lists of goods: a list for which the difference in tariff rates among the EAEC members does not exceed 5 percentage points, and a list for which it does. Moreover, during the transitional period (i.e., before the full implementation of the EAEC), each member is to determine a list of sensitive goods for which it will be free to establish its own rates. Such a list should not exceed 15 percent of the total imports of the country in the preceding year. ${ }^{14}$ The exception is Tajikistan, which has only one sensitive item, alumina, for which imports should not exceed 25 percent of the corresponding imports of the previous year. The level of harmonization of tariff lines between current members' tariff structures

\footnotetext{
12 The CIS customs union was originally signed in early 1995 by Belarus and the Russian Federation, followed by Kazakhstan in late 1995, the Kyrgyz Republic in March 1996, and finally by Tajikistan in February 1999, but never entered into force.

13 The CET agreement came into force in 2000 for Belarus, the Kyrgyz Republic, the Russian Federation, and Tajikistan, and in 2001 for Kazakhstan.

${ }^{14}$ Article 1 of the agreement defines sensitive goods as goods that are not produced, or are produced in insufficient quantities, in the member states and that are of social importance-i.e., necessary for the satisfaction of the population's vital needs or national production-and also goods for which domestic producers need governmental support and protection from competition of like imported goods.
} 
and that of the EAEC varies across countries, with the Kyrgyz Republic having the lowest level of harmonization equal to 32 percent of the common tariff schedule in 2003.

Regional institutions governing the EAEC include the interstate council - the supreme body of the EAEC; the integration committee; and the interparliamentary assembly. The Russian Federation dominates the interstate council with four votes, Belarus and Kazakhstan each have two votes, and the Kyrgyz Republic and Tajikistan each have one vote. In May 2003, the EAEC member countries met for the first time to seek ways to improve their customs union agreement and to coordinate their efforts to gain accession to the WTO (see Section V).

\section{Common Economic Space}

On September 19, 2003 Belarus, Kazakhstan, the Russian Federation, and Ukraine met in Yalta to sign a draft agreement to create a CES over 5-7 years. The process involves three stages: the coordination of customs duties and harmonization of trade and custom regulations; the lifting of current trade barriers and creation of the customs union; and the liquidation of internal customs boundaries to be replaced by a common customs boundary and the creation of a supra-national regulating institution.

At this stage, Ukraine's position is still not fully defined because Ukraine has also expressed interest in joining the EU. More generally the EAEC and CES initiatives seem to overlap at least for some of the members, and, for them it is not clear at this stage how joining the CES will differ from joining the EAEC. Membership in different customs unions is, of course, not possible.

\section{Other Regional Cooperation Initiatives}

CIS members participate in several other regional cooperation agreements. These include, among others, the GUUAM, which was initially set up with the goal of developing hydrocarbon pipeline projects, but more recently presented a proposal to create a free trade area; the Shanghai Cooperation Organization, which originally focused on regional security but more latley has approved programs on the promotion of trade and investment; and the Central Asia Cooperation Organization (CACO). At the CACO summit in October 2004, Uzbekistan proposed establishing a Central Asian Common Market to deepen integration among member countries, with the initial goal of attracting foreign investment and boosting economic growth. In February 2005, Kazakhstan proposed the creation of a Central Asian Union based on the European Union (EU) model.

\section{Current Status of the CIS Trade Regimes}

CIS member countries, with the exception of Belarus, Turkmenistan, and Uzbekistan, are generally open economies, although the degree of openness varies. Kazakhstan and the Russian Federation are more restrictive, while the CIS-5 countries are the most liberal 
(Table 2). ${ }^{15}$ Despite the de jure liberal trade regimes in most of the CIS, unofficial and nontransparent barriers, including corruption, present obstacles to liberal trade. The tariff level is not always in itself an obstacle to trade, but the lack of transparent custom valuation procedures is. Trade policy openness does not always correspond to trade openness.

Table 2. Selected Trade Regime Indicators in the CIS, 2003

\begin{tabular}{lccccc}
\hline & $\begin{array}{c}\text { Number of } \\
\text { bands }\end{array}$ & $\begin{array}{c}\text { Minimum } \\
\text { tariff }(\%)\end{array}$ & $\begin{array}{c}\text { Maximum } \\
\text { tariff }(\%)\end{array}$ & $\begin{array}{c}\text { Average } \\
\text { tariff }(\%)\end{array}$ & $\begin{array}{c}\text { Custom fees } \\
(\%)\end{array}$ \\
\hline Armenia & 2 & 0 & 10 & 4.0 & 0.00 \\
Azerbaijan & 3 & 0 & 15 & 10.8 & 0.15 \\
Belarus & 8 & 0 & 100 & 11.0 & 0.15 \\
Georgia & 22 & 0 & 30 & 8.2 & 0.15 \\
Kazakhstan & 10 & 1 & 100 & 7.4 & 0.20 \\
Kyrgyz Republic & 5 & 0 & 20 & 4.5 & 0.15 \\
Moldova & 6 & 0 & 15 & 6.9 & 0.00 \\
Russia & 10 & 0 & 100 & 11.1 & 0.00 \\
Tajikistan & 6 & 0 & 15 & 7.6 & 0.00 \\
Turkmenistan & 6 & 10 & 100 & 5.1 & 0.50 \\
Ukraine & 5 & 0 & 70 & 12.7 & 0.00 \\
Uzbekistan & 3 & 0 & 30 & 15.3 & 0.20 \\
\hline
\end{tabular}

Sources: Country authorities; and Fund staff calculations.

The simulations from gravity models suggest that the CIS countries do not trade "enough" relative, for example, to other transition economies. ${ }^{16}$ This result reflects specific constraints and obstacles to trade in the CIS: economic structure (some of the CIS countries rely mainly on natural resources); geographic conditions (e.g., Belarus, the Kyrgyz Republic, Tajikistan, Turkmenistan, and Uzbekistan are landlocked); unresolved external and internal conflicts (e.g., between Armenia and Azerbaijan, within Georgia, and within the Russian Federation); and the cost of transit trade; ${ }^{17}$ the existence of unofficial payments; and excessive regulation. Moreover, the large number of free trade agreements in the region and the plethora of inconsistent rules of origin represent additional barriers, not only because of the increased scope for corruption but also because uncertainty about the rules creates trade disputes, retaliation, and a climate of distrust among the CIS members.

\footnotetext{
${ }^{15}$ The CIS-5 comprises Armenia, Georgia, the Kyrgyz Republic, Moldova, and Tajikistan.

${ }^{16}$ Elborgh-Woytek (2003). See Lissovolik and Lissovolik (2004) for a gravity model applied to the case of Russia.

${ }^{17}$ For example, problems of transit trade include rail, roads, poor infrastructure and air transportation. Transport markets are fragmented, and therefore the CIS countries with the exception of Kazakhstan, Turkmenistan, and Russia, do not enjoy economies of scale in their operations. Despite its dominant position in gas exports to Europe, Russia still needs to rely on the Ukrainian transit route, while Kazakhstan depends on the Russian Transneft pipeline, and on Georgia, and Azerbaijan depends on Georgia as well.
} 


\section{Comparison of EAEC Members' Tariff Structure with the EAEC Common External Tariff}

For all EAEC members, with the exception of Belarus and the Russian Federation, the implementation of the EAEC tariff schedule implies an increase in their simple average tariff and in the MFN tariff for most tariff lines covered by the EAEC common tariff, especially for manufactures, while for Belarus and Russia the adoption of the EAEC tariff schedule implies a small decrease in their average tariff (Table 3 ).

EAEC members currently have relatively low tariff rates on products that they do not produce (e.g., cars and alcohol in the Kyrgyz Republic as opposed to Russia, which has higher rates on these items). Therefore, the EAEC, by implying an increase in the tariff schedule to accommodate the more protectionist sectors of each member, implies an increase of the overall trade protection of its members. Such an increase will be particularly dramatic for the Kyrgyz Republic and Tajikistan. The latter has, in fact, already increased its tariff rates in 2003 to comply with EAEC commitments.

Because harmonization to the EAEC tariff schedule is still incomplete, a further increase in Tajikistan's tariff rates - as well as in those of the other more liberal EAEC countries - is necessary before 2006, when the EAEC will be fully implemented. Given that the Kyrgyz Republic's WTO bound rates on many tariff lines are lower than the EAEC rates, adopting the EAEC rates could be inconsistent with the Kyrgyz Republic's WTO commitments.

\section{Estimation OF THE WELFARE EFFECT OF EAEC CUSTOMS UNiON MEMbERSHIP}

\section{A. The Model}

A simple partial equilibrium model is employed to simulate the welfare impact on each EAEC member of two possible sequencing paths: adopting the EAEC common external tariff prior to WTO accession (first scenario), and adopting the EAEC common external tariff after having joined the WTO (second scenario). The model uses commodity-level imports and tariff data at the four-digit level of the Harmonized System. ${ }^{18}$

The EAEC countries are currently applying a zero tariff rate to their intra-EAEC trade, and the model assumes they will continue to do so after the implementation of the customs union. Other specific assumptions of the model are that products imported from EAEC members are imperfect substitutes for products traded with the rest of the world; that world markets are perfectly competitive; and that within each group (i.e., EAEC members and the rest of the world) the products traded are perfectly homogeneous.

\footnotetext{
${ }^{18}$ The theoretical framework underlying this simplified model follows Francois and Hall (1997) as well as Hoekman, Ng, and Olarreaga (2002), modified to account for the impact of joining a customs union.
} 
Table 3. EAEC Members' Current Tariff Structure Compared with the EAEC Tariff Rates

\begin{tabular}{|c|c|c|c|c|c|c|}
\hline & EAEC & BLR & KAZ & KGZ & WTO KGZ $^{1}$ & $\mathrm{RUS}^{2}$ \\
\hline Simple average ${ }^{3}$ & 10.4 & 11.0 & 7.4 & 4.5 & 7.3 & 11.1 \\
\hline $\begin{array}{l}\text { Agricultural products } \\
\text { of which: }\end{array}$ & 12.4 & 14.1 & 11.7 & 8.5 & 7.9 & 13.4 \\
\hline Alcohol & 32.1 & 21.0 & 100 & 7.9 & 11.8 & 21.0 \\
\hline Tobacco & 10.8 & 11.0 & 11.5 & 3.9 & 12.3 & 10.8 \\
\hline $\begin{array}{l}\text { Mining } \\
\text { of which: }\end{array}$ & 5.1 & 5.1 & 4.8 & 4.8 & 9.6 & 5.1 \\
\hline Gas & $\ldots$ & 5.0 & 4.3 & 5.0 & 10.0 & 5.0 \\
\hline Oil and oil products & 5.0 & 5.0 & 5.0 & 5.0 & 10.0 & 5.0 \\
\hline $\begin{array}{l}\text { Manufactures } \\
\text { of which: }\end{array}$ & 9.7 & 10.2 & 6.2 & 3.2 & 6.5 & 10.6 \\
\hline Passenger cars & $\ldots$ & 16.1 & 7.0 & 0.0 & 10.0 & 16.1 \\
\hline Maximum & 100 & 100 & 100 & 20 & 30 & 100 \\
\hline Minimum & 0 & 0 & 0 & 0 & 0 & 0 \\
\hline Standard Deviation & 5.8 & 6.1 & 6.6 & 4.8 & 4.6 & 6.8 \\
\hline Number of lines & 6,156 & 11,166 & 10,993 & 11,152 & 6,892 & 11,166 \\
\hline Bands & $\begin{array}{c}0,5,10,15,20,25,30 \\
100\end{array}$ & $\begin{array}{c}0,5,10,15,20,25,30 \\
100\end{array}$ & $\begin{array}{c}0,1,2,5,10,15,20,25 \\
30,100\end{array}$ & $0,5,10,15,20$ & $\begin{array}{l}0,5,5.5,6.5,7,8,10 \\
12,15,20,30\end{array}$ & $\begin{array}{c}0,5,10,15,20,25,30,60 \\
80,100\end{array}$ \\
\hline
\end{tabular}

Sources: Country authorities; the WTO and Fund staff estimates.

$1 /$ WTO commitments. Not all products are bound.

2/ Although more than 90 percent of tariffs are between 0 and 20 percent, on some products protection is much higher: 100 percent tariff rate on undenatured ethyl alcohol,

80 percent on pork, 30 percent on cigarette and cigars, 25 percent on some meat items and on some passengers cars.

3 / Includes ad valorem portions of mixed duty rates. 
The welfare effects in each scenario are divided between the change in consumer surplus and the change in tariff revenues and are further decomposed into effects deriving from trade among EAEC members and trade with non-EAEC partners (i.e., the rest of the world). The model also simulates the impact on imports.

The change in welfare $\left(\Delta W_{i}\right)$ for each member $i$ of the EAEC - Belarus, Kazakhstan, the Kyrgyz Republic, the Russian Federation, and Tajikistan - following the implementation of the EAEC customs union is the sum of two welfare changes: that resulting from the adoption of the new MFN tariff applied by each EAEC member vis-à-vis nonmembers and that of the preferential tariff between the EAEC members:

$$
\begin{aligned}
& \Delta W_{i}=\Delta W_{i, R O W}+\Delta W_{i, E A E C} \\
= & \Delta T R_{i, R O W}+\Delta C S_{i, R O W}+\Delta T R_{i, E A E C}+\Delta C S_{i, E A E C}
\end{aligned}
$$

where $\triangle W_{i, R O W}$ is the welfare change of member $i$ owing to changes in tariff revenues $\left(\triangle T R_{i, R O W}\right)$ and consumer surplus $\left(\triangle C S_{i, R O W}\right)$, due to the new MFN (EAEC) tariff applied visà-vis nonmembers, and $\triangle W_{i, E A E C}$ is the welfare change owing to changes in tariff revenues $\left(\triangle T R_{i, E A E C}\right)$ and consumer surplus $\left(\triangle C S_{i, E A E C}\right)$, due to the preferential tariff granted by member $i$ to the other EAEC countries.

The import demand, $M_{i}$, calculated as the sum of each import demand for each commodity of member $i$ of the EAEC, is given by

$$
M_{i}=\frac{A_{i}}{\left[P_{w, i}\left(1+t_{i}\right)\right]^{\eta}}
$$

where $A_{i}$ is a demand parameter, $P_{w, i}$ is the world price, normalized at $1, t_{i}$ is the MFN tariff, and $\eta$ is the elasticity of import demand, which varies across products.

The demand parameter, which is equal to $A_{i}=M_{i}\left[P_{w, i}\left(1+t_{i}\right)\right]^{\eta}$, is unknown. In the model, A is calibrated assuming the elasticity of import demand, $\eta$, from Hoekman, $\mathrm{Ng}$, and Olarreaga (2002) and Kee, Nicita, and Olarreaga (2004), actual imports from UN trade data at the fourdigit level of the Harmonized System, and MFN tariffs provided by country authorities.

\section{Change in Imports}

After member $i$ joins the EAEC, the initial MFN tariff, $t_{i}^{I}$, changes to $t_{i}^{F}$, which is equal to the initial MFN tariff multiplied by the parameter $\alpha$, while the tariff rate for imports traded within the EAEC remains zero. ${ }^{19}$ The change in imports of member $i$ from the rest of the world after adopting the EAEC rate, $\triangle M_{R O W}$, will be expressed by

\footnotetext{
${ }^{19}$ The parameter $\alpha$ varies across products.
} 


$$
\Delta M_{i, \text { ROW }}=M_{i, \text { ROW }}^{F}-M_{i, \text { ROW }}^{I}=\frac{A_{i, \text { ROW }}}{\left[P_{w, i}\left(1+t_{i}^{I} \alpha_{i}\right)\right]^{\eta}}-\frac{A_{i, \text { ROW }}}{\left[P_{w, i}\left(1+t_{i}^{I}\right)\right]^{\eta}}
$$

with $M^{I}{ }_{i, R O W}$ representing the initial pre-EAEC imports from the rest of the world and $M_{i, R O W}^{F}$ the final imports from the rest of the world after adoption of the EAEC rate.

The impact on imports from EAEC countries is obtained by rewriting (3) for $\alpha$ equal to zero:

$$
\Delta M_{i, E A E C}=M_{i, E A E C}^{F}-M_{i, E A E C}^{I}=\frac{A_{i, E A E C}}{P_{w, q}^{\eta}}-\frac{A_{i, E A E C}}{\left[P_{w, q}^{\eta}\left(1+t_{i}^{I}\right)\right]^{\eta}}=0
$$

because the tariff rate $t_{i}^{I}$ applied to intra-EAEC trade prior to the customs union implementation is assumed to be zero.

\section{Impact on Tariff Revenues}

Using the following definitions:

$$
T R_{i, \text { ROW }}^{I}=t_{i}^{I} P_{w, i} M_{i, \text { ROW }}^{I} \text { and } T R_{i, \text { ROW }}^{F}=t_{i}^{I} \alpha_{i} P_{w, i} M_{i, \text { ROW }}^{F}
$$

and substituting from above the change in tariff revenues with the rest of the world, $\triangle T R_{i, R O W}$ in country $i$ is equal to

$$
\begin{aligned}
\Delta T R_{i, R O W} & =T R_{i, \text { ROW }}^{F}-T R_{i, \text { ROW }}^{I}=t_{i}^{I} \alpha_{i} P_{w, i} \frac{A_{i, \text { ROW }}}{\left[P_{w, i}\left(1+\left(t_{i}^{I} \alpha_{i}\right)\right)\right]^{\eta}}-t^{I} P_{w} \frac{A_{i, R O W}}{\left[P_{w, i}\left(1+t_{i}^{I}\right)\right]^{\eta}} \\
& =t_{i}^{I} P_{w, i}^{1-\eta} A_{i, \text { ROW }}\left[\frac{\alpha_{i}}{\left(1+t_{i}^{I} \alpha_{i}\right)^{\eta}}-\frac{1}{\left(1+t_{i}^{I}\right)^{\eta}}\right]
\end{aligned}
$$

where $\triangle T R_{i, R O W}^{I}$ is the initial tariff revenues from the rest of the world before converging toward the EAEC rate, and $\triangle T R_{i, R O W}^{F}$ is the tariff revenues after converging to the EAEC rate.

The impact on tariff revenues deriving from EAEC imports after applying a zero tariff rate $(\alpha=0)$ is

$$
\Delta T R_{i, E A E C}=T R_{i, E A E C}^{F}-T R_{i, E A E C}^{I}=-\left[\frac{t_{i}^{I} P_{w, i}^{1-\eta} A_{i}}{\left(1+t_{i}^{I}\right)^{\eta}}\right]=0
$$

because $t_{i}^{I}$ is equal to zero, if the EAEC countries apply a zero tariff rate to their intra-EAEC trade.

The change in the consumer surplus due to the change of the MFN tariff is defined as 


$$
\begin{gathered}
\Delta C S_{i, R O W}=\int_{P_{w}\left(1+t^{i}\right)}^{P w\left(1+t^{F}\right)} \frac{A}{P^{\eta}} d P=\frac{A_{i, R O W}}{\eta-1}\left[\frac{1}{\left[P_{w, i}\left(1+t_{i}^{F}\right)\right]^{\eta-1}}-\frac{1}{\left[P_{w, i}\left(1+t_{i}^{I}\right)\right]^{\eta-1}}\right] \\
=\frac{1}{\eta-1} A_{i, R O W} P_{w, i}^{1-\eta}\left[\frac{1}{\left[\left(1+t_{i}^{I} \alpha\right)\right]^{\eta-1}}-\frac{1}{\left[\left(1+t_{i}^{I}\right)\right]^{\eta-1}}\right]
\end{gathered}
$$

The change in the consumer surplus within the EAEC $(\alpha=0)$ is

$$
\Delta C S_{i, E A E C}=\frac{1}{\eta-1} A_{i, E A E C} P_{w, i}^{1-\eta}\left[1-\frac{1}{\left[\left(1+t_{i}^{I}\right)\right]^{\eta-1}}\right]
$$

\section{B. Scenarios and Results of the Simulation}

Two scenarios are provided to estimate the welfare effects of the sequencing paths alternatives. The results of these simulations show that the welfare impact of each different choice varies across countries. In particular, the impact depends on how the current tariff schedule of each EAEC member compares to the EAEC tariff schedule (Table 3 above).

\section{Scenario 1: EAEC Customs Union Implementation Prior to WTO Accession}

The first scenario (Table 4) assumes that EAEC members will change their MFN tariffs visà-vis the rest of the world to match the current EAEC CET before joining the WTO. Because not all EAEC rates have been agreed as yet, this scenario assumes the highest rate currently prevailing among the EAEC members on those lines for which the tariffs have not yet been bound. This assumption is justified by the fact that the tariff lines not yet bound correspond mostly to goods that are produced in the EAEC countries, and therefore there is a strong incentive to maintain the rate of protection on these products. Because the Kyrgyz Republic has already joined the WTO, the results of the simulation for the Kyrgyz Republic should be interpreted as the costs of implementing the EAEC customs union. ${ }^{20}$

According to these simulations, Kazakhstan, the Kyrgyz Republic, and Tajikistan will incur welfare losses that will be borne ultimately by the consumers of these countries. The loss in consumer surplus that derives from the increase in the MFN tariff compared to the current tariff is, in fact, only partially offset by the increase in tariff revenues due to higher MFN tariffs being applied to imports from non-EAEC countries. Moreover, given the assumption that access is completely free among EAEC countries, even before the implementation of the EAEC customs union, there is no positive change in consumer surplus deriving from imports from other EAEC members after implementation of the EAEC customs union because there

\footnotetext{
${ }^{20}$ See Michalopoulos and Tarr (1997) for an analytical discussion on the cost of implementing a customs union in the CIS.
} 
is no decrease in the tariff rates, which will continue to be zero. That is to say the model does not allow for a trade creation effect resulting from trade among the EAEC partners.

Because the simulation predicts a decline in imports from non-EAEC members in Kazakhstan, the Kyrgyz Republic, and Tajikistan after adoption of the EAEC tariff schedule, as a result of higher MFN tariffs, and because this decline will not be offset by an increase in imports from EAEC countries (Table 4), the aggregate impact is net trade diversion. ${ }^{21}{ }^{22}$

Table 4. Scenario 1: Impact on Welfare of EAEC Customs Union Implementation Prior to WTO Accession (In millions of U.S. dollars unless otherwise indicated)

\begin{tabular}{|c|c|c|c|c|c|}
\hline & BLR & KAZ & $\mathrm{KGZ}^{1}$ & RUS & TJK \\
\hline Change in welfare & 2.6 & -31.8 & -3.5 & 142.8 & -1.8 \\
\hline EAEC & 0.0 & 0.0 & 0.0 & 0.0 & 0.0 \\
\hline Rest of the world & 2.6 & -31.8 & -3.5 & 142.8 & -1.8 \\
\hline \multicolumn{6}{|l|}{ of which: } \\
\hline Change in tariff revenues & 3.0 & 223.4 & 22.8 & -150.3 & 12.1 \\
\hline EAEC & 0.0 & 0.0 & 0.0 & 0.0 & 0.0 \\
\hline Rest of the world & 3.0 & 223.4 & 22.8 & -150.3 & 12.1 \\
\hline Change in consumer surplus & -0.4 & -255.2 & -26.3 & 293.0 & -13.8 \\
\hline EAEC & 0.0 & 0.0 & 0.0 & 0.0 & 0.0 \\
\hline Rest of the world & -0.4 & -255.2 & -26.3 & 293.0 & -13.8 \\
\hline Change in tariff revenues (percentage change) & 0.9 & 90.8 & 202.2 & -2.8 & 53.0 \\
\hline EAEC & 0.0 & 0.0 & 0.0 & 0.0 & 0.0 \\
\hline Rest of the world & 0.9 & 90.8 & 202.2 & -2.8 & 53.0 \\
\hline Change in imports (percentage change) & 0.0 & -6.1 & -6.6 & 0.3 & -3.6 \\
\hline EAEC & 0.0 & 0.0 & 0.0 & 0.0 & 0.0 \\
\hline Rest of the world & -0.1 & -10.3 & -13.1 & 0.3 & -5.2 \\
\hline
\end{tabular}

Sources: Author's estimates, based on country authorities' data for MFN and EAEC tariffs and UN Comtrade statistics for trade data.

1/ Because the Kyrgyz Republic has already joined the WTO, the results should be interpreted as the costs of implementing the EAEC customs union.

For Belarus and Russia there will be small welfare gains from the adoption of the EAEC tariff schedule.

\footnotetext{
${ }^{21}$ Trade diversion would be less of an issue for free trade areas because each member would be allowed to decrease its import tariffs unilaterally and therefore switch imports to the most efficient supplier as long as it would be easy to enforce the rules of origin.

${ }^{22}$ One of the conditions for minimizing trade diversion is that partners in a customs union are not to raise their trade barriers relative to the rest of the world after joining the customs union. The economic analysis of customs unions in terms of their trade creation and trade diversion effects dates back to the pioneering work of Viner (1950).
} 


\section{Scenario 2: EAEC Customs Union Implementation after WTO Accession}

Because EAEC members - with the exception of the Kyrgyz Republic, which has already acceded to the WTO - are still negotiating the bound rates with the WTO, these rates are not yet known. Therefore, the second scenario assumes that the prevailing EAEC CET, after WTO accession, will include the existing CET lines and the lowest rates currently effective among EAEC members for lines that have not yet been bound. The assumption is that the incentive to raise tariffs in order to protect the interests of EAEC members as a group, as well as their bargaining power will be less compelling in negotiations with the WTO, if the interests of the EAEC do not take precedence over individual country interests. This would be true especially if smaller countries were to accede first.

The results of the simulations show larger welfare gains for Russia and Belarus compared to the opposite sequencing path depicted in Scenario 1, as well as smaller losses in consumer surplus for Kazakhstan, the Kyrgyz Republic, and Tajikistan compared to the first scenario (Table 5).

Table 5. Scenario 2: Impact on Welfare of EAEC Customs Union Implementation Following WTO Accession (In millions of U.S. dollars unless otherwise indicated)

\begin{tabular}{|c|c|c|c|c|c|}
\hline & BLR & KAZ & KGZ & RUS & TJK \\
\hline Change in welfare & 16.9 & -2.4 & - & 419.0 & -0.7 \\
\hline EAEC & 0.0 & 0.0 & - & 0.0 & 0.0 \\
\hline Rest of the world & 16.9 & -2.4 & - & 419.0 & -0.7 \\
\hline \multicolumn{6}{|l|}{ of which: } \\
\hline Change in tariff revenues & -116.3 & 16.9 & - & -2193.1 & 3.8 \\
\hline EAEC & 0.0 & 0.0 & - & 0.0 & 0.0 \\
\hline Rest of the world & -116.3 & 16.9 & - & -2193.1 & 3.8 \\
\hline Change in consumer surplus & 133.3 & -19.4 & - & 2612.1 & -4.5 \\
\hline EAEC & 0.0 & 0.0 & - & 0.0 & 0.0 \\
\hline Rest of the world & 133.3 & -19.4 & - & 2612.1 & -4.5 \\
\hline Change in tariff revenues (percentage change) & -34.4 & 6.9 & - & -40.8 & 16.6 \\
\hline EAEC & 0.0 & 0.0 & - & 0.0 & 0.0 \\
\hline Rest of the world & -34.4 & 6.9 & - & -40.8 & 16.6 \\
\hline Change in imports (percentage change) & 2.4 & -0.6 & - & 8.5 & -1.1 \\
\hline EAEC & 0.0 & 0.0 & - & 0.0 & 0.0 \\
\hline Rest of the world & 7.1 & -0.9 & - & 9.7 & -1.6 \\
\hline
\end{tabular}

Sources: Author's estimates, based on country authorities' data for MFN and EAEC Tariffs and UN Comtrade statistics for trade data.

\section{Caveats}

The results show that the welfare effects of joining the EAEC prior to WTO accession are negative from a consumer standpoint in member countries whose tariff rates are currently lower than the ones implied by the EAEC tariff schedule, while these effects are positive for the EAEC as a group, given the positive impact on Russia. These consumer losses will be mitigated in the event that implementation of the EAEC follows WTO accession (second scenario), under the assumption that the EAEC CET would be lower in this case. The second scenario, however, does not try to simulate the gains from joining the WTO per se, which is 
beyond the scope of this paper, but to quantify the minimum amount of welfare gain compared to the scenario in which the EAEC implementation precedes WTO accession. In this sense, the results of the simulations provide only a range of values, and the actual direction of the welfare changes is considered to be more indicative than an exact quantification of the welfare effects. ${ }^{23}$

Finally, the model does not attempt to assess the welfare implications of joining the EAEC as a political and economic entity, but only the welfare implications resulting from the implementation of the EAEC customs union.

\section{WTO ACCESSION AND THE EAEC CUSTOMS UNION: NEGOTIATION ISSUES AND IMPLICATIONS FOR SEQUENCING}

While pursuing regional integration, many of the CIS countries are still in the process of accession to the WTO (Table 6). Within the EAEC, only the Kyrgyz Republic has already acceded to the WTO. ${ }^{24}$ The choice of sequencing between WTO accession and the implementation of a customs union also depends on how WTO negotiations are handled (i.e., through an individual or a cooperative approach).

In the mid-1990s, when most of the CIS countries applied to the WTO, there was no implicit coordination strategy: each country approached accession independently. A coordinated approach to pursuing WTO membership in accordance with EAEC commitments was explicitly endorsed in May 2003 by the presidents of the non-WTO members of the EAEC and was recently reiterated in Almaty, Kazakhstan, in June 2004.

EAEC members favor a cooperative approach to gaining accession to the WTO to strengthen their bargaining power as a group and avoid undercutting each other. ${ }^{25}$ For example, accession terms negotiated by the Kyrgyz Republic in 1998 were perceived by the other EAEC members to have weakened their negotiating position vis-à-vis the WTO, ${ }^{26}$ given that

\footnotetext{
${ }^{23}$ The model uses statutory rates to run the simulations. These rates are biased upward relative to the actual tariff rates due to the existence of exemptions, shuttle trade, and bilateral preference rules even outside of the EAEC member countries. Therefore, import duties used in the model in the base year may differ from actual collected tariff revenues.

${ }^{24}$ The most recent example of parallel accession to the WTO and customs union membership is given by the Baltic countries membership in the EU. However, cases of sequencing that involve first WTO membership and then customs union membership are more numerous.

${ }^{25}$ Coordination might also imply lower costs of finalizing the negotiations with the WTO for the poorer countries.

${ }^{26}$ See Yang (2003).
} 
the Kyrgyz tariff bindings are lower on average than tariffs prevailing in the other EAEC countries (Table 3 above). ${ }^{27}$

Table 6. WTO Accession Status of the CIS, 2004

\begin{tabular}{lcc}
\hline & Application & Current Status \\
\hline Armenia & Nov-93 & Joined in 2003 \\
Azerbaijan & Jul-97 & Ongoing negotiations \\
Belarus & Sep-93 & Ongoing negotiations \\
Georgia & Jul-96 & Joined in 2000 \\
Kazakhstan & Jan-96 & Ongoing negotiations \\
Kyrgyz Republic & Feb-96 & Joined in 1998 \\
Moldova & Nov-93 & Joined in 2001 \\
Russia & Jun-93 & Ongoing negotiations \\
Tajikistan & May-01 & Ongoing negotiations \\
Turkmenistan & $\ldots$ & $\ldots$ \\
Ukraine & Nov-93 & Ongoing negotiations \\
Uzbekistan & Dec-94 & Ongoing negotiations \\
\hline
\end{tabular}

Source: WTO.

The coordinated approach, however, not only implies a higher ex post rate of protection of the EAEC members as a group, but also eliminates the possibility to pursue WTO accession at different paces. The welfare implications of this outcome are not the same across EAEC countries: if EAEC members had engaged in a competitive process to gain WTO accession, this would have strengthened the trade leverage of those EAEC countries that had acceded earlier over those still in the accession process. This leverage might have been impossible to achieve in bilateral negotiations outside the WTO framework, given the imbalance in economic power among EAEC members. ${ }^{28}$ This was the case of the Kyrgyz Republic.

Moreover, a coordinated approach might result in a higher ex post level of protection of the EAEC countries vis-à-vis EAEC nonmembers. Implementation of EAEC customs union is not yet complete, and there is still some degree of flexibility in establishing the tariff lines, which are not yet bound under the EAEC customs union. Because of Russia's dominant position in the negotiations, however, and because its trade policy is more protectionist and

\footnotetext{
${ }^{27}$ Indeed, the WTO terms negotiated by the Kyrgyz Republic provoked tensions with the other CIS countries who, in response, introduced some discriminatory measures against Kyrgyz agricultural products.

${ }^{28}$ For example, if one EAEC member not yet a member of the WTO had imposed measures against the exports of another EAEC member already a member of the WTO, it would have been possible for the latter to extract concessions from the former within the WTO framework by sitting on the accession working party of the EAEC applicant country. See Roberts and Wehrheim (2001) for a discussion.
} 
closer to the EAEC tariff structure than those of the other EAEC countries, some of the more liberal members might be inclined to converge toward Russia's higher tariff rates in order to pursue common terms of accession. Although negotiations with the WTO are conducted on an individual basis, in the case of the CIS the Russian Federation provides a reference point for the other CIS countries not yet members of the WTO, ${ }^{29}$ and it is conceivable that only after Russia's accession to the WTO will the remaining CIS countries pursuing accession be able to finalize their negotiations.

The prospects of a customs union among members of the EAEC may have already complicated the WTO accession process and increased the length of negotiations because of the need to reconcile commitments under the EAEC with the common terms of accession for WTO membership. Russia's trade policy is more complex than those of other CIS members. Russia also has active lobbies representing constituencies in the automobile, aircraft, agriculture, and gas sectors that might possibly attempt to discourage trade liberalization because of the likelihood of losing economic rents derived from trade protection. Moreover, the larger CIS countries may not have the same incentives as some of the other countries to join the WTO as early as possible because the former may be more interested in the terms of accession rather than in its timing and speed. These factors are all causing delays.

Last but not least, the Kyrgyz Republic is already a member of the WTO and its tariff bindings that were negotiated are lower than the CET under the EAEC (Table 4). It is unlikely, however, that EAEC members will lower the CET to satisfy compatibility between Kyrgyz WTO and EAEC commitments. Therefore, it is possible that if the Kyrgyz Republic fully implements the EAEC common tariff, it will violate its WTO commitments, which may lead to demands for compensation from other WTO members. ${ }^{30}$

\section{Conclusions}

The choice of the appropriate sequencing between WTO accession and membership in a customs union should be evaluated carefully by all countries concerned, given that the welfare implications of the two sequencing paths may vary considerably. The welfare impact would depend on the individual country's trade preferences, its bargaining power, and the size of its economy. If one of the members of the customs union is already a WTO member, this may create compatibility issues between WTO and customs union commitments. In this case, the common external tariff should be set to the lowest rate among members. This also minimizes the risk of trade diversion and an overall increase in protection.

\footnotetext{
${ }^{29}$ Lissovolik and Lissovolik (2004).

${ }^{30}$ A WTO member can still benefit from joining a customs union, provided that its rate of protection does not increase as a result of it. Regional trade integration can serve as a vehicle for dialogue and coordination on regional issues that are not part of the multilateral agenda. These might include regulatory harmonization, infrastructure development, and collaboration among members to facilitate transit trade and transport which are particularly critical among the CIS members.
} 
This analysis of the EAEC tariff structure suggests that the level of trade protection of the Kyrgyz Republic, Kazakhstan, and Tajikistan will increase once the customs union is fully implemented because of the need for customs union members to harmonize their current tariff structures to that of the EAEC. In particular, consumers in the Kyrgyz Republic, Kazakhstan, and Tajikistan would bear the costs of joining the EAEC customs union because these countries may have to increase their tariff rates to meet EAEC commitments.

The results of the simulations of the two sequencing paths show that joining the WTO ahead of implementing the EAEC customs union is welfare improving compared to the opposite sequencing path from a consumer standpoint. Moreover, net trade diversion differs across members because of the difference in their current levels of trade protection.

The prospect of fully implementing the EAEC has already increased the overall rate of protection in the region (e.g., for Tajikistan) in order to comply with the customs union commitments, and it may have prolonged WTO negotiations and delayed the accession process. This is because the EAEC countries must harmonize their CET commitments with the common terms of accession under the WTO by reconciling very different interests in the region. Moreover, pursuing common terms of accession can lead to considerable delays that can be detrimental for small open economies that would benefit from more rapid accession. These delays in acceding to the WTO may impose cost on more liberal countries in terms of missed opportunities to extract concessions from the customs union's more protectionist members.

This study suggests that there are reasons to be cautious about the implementation of the customs union envisaged by the EAEC. First, there could be welfare losses for some countries as a result of trade diversion due to an increase in the rate of protection. Second, the harmonization process could possibly benefit certain countries more than others. Finally, even though a customs union does not limit in principle the scope for future multilateral liberalization if pursued first, it slows down decision making because of the need to coordinate positions, it gives protectionist lobbies in some countries leverage over the trade policies of other more liberal countries, and it may delay the WTO accession process. 


\section{Regional Cooperation Agreements and Initiatives in the CIS}

Economic Cooperation and Organization, 1992: Islamic State of Afghanistan, Islamic Republic of Azerbaijan, Islamic Republic of Iran, Kazakhstan, the Kyrgyz Republic, Pakistan, Tajikistan, Turkey, Turkmenistan, and Uzbekistan.

Black Sea Economic Cooperation, 1992: Armenia, Azerbaijan, Georgia, Moldova, the Russian Federation, and Ukraine.

Energy Charter Treaty, 1994: signed by all Central Asian countries and most European countries.

CIS Free Trade Agreement, 1994: Armenia, Belarus, Georgia, Moldova, Kazakhstan, the Kyrgyz Republic, the Russian Federation, Tajikistan, Ukraine, and Uzbekistan. It has not been ratified by a number of states.

$>\quad$ GUUAM, 1997: Azerbaijan, Georgia, Moldova, Ukraine, and Uzbekistan. Initially set up with the goal of developing hydrocarbon pipeline projects. A proposal to create a Free Trade Area was made in 2000.

> Central Asia Cooperation Organization (CAREC), 1997: Azerbaijan, People's Republic of China (focusing on Xinjiang Uygur Autonomous Region), Kazakhstan, Kyrgyz Republic, Mongolia, Tajikistan, Uzbekistan.

$>\quad$ Eurasian Economic Community, signed in 2000, ratified in May 2001. It includes Belarus, Kazakhstan, the Kyrgyz Republic, the Russian Federation, and Tajikistan.

Shanghai Cooperation Organization, 2001: China, Kazakhstan, the Kyrgyz Republic, the Russian Federation, and Tajikistan.

Central Asia Cooperation Organization (CACO), 2002: Kazakhstan, the Kyrgyz Republic, the Russian Federation, Tajikistan and Uzbekistan.

Common Economic Area, September 2003: draft agreement between Belarus, Kazakhstan, the Russian Federation, and Ukraine.

Agreement on Partnership and Cooperation between Moldova and the EU, 1994. It became effective in 1998.

Agreement on Partnership and Cooperation between the EU and Uzbekistan, 1996. The main goal is economic cooperation.

Agreement on Partnership and Cooperation between the EU and the Russian Federation, 1998.

Agreement on Partnership and Cooperation between the EU and Turkmenistan, 1998. 
Balkan Stability Pact, 1999: signed by Albania, Bosnia and Herzegovina, Bulgaria, Croatia, the former Yugoslav Republic of Macedonia, Moldova, Romania, Turkey and the Federal Republic of Yugoslavia. In 2002 it admitted the Czech Republic, Poland and the Slovak Republic.

$>\quad$ Caspian Sea Oil and Gas agreements, November 1999: Signed by Azerbaijan, Georgia, Kazakhstan, Turkey, and Turkmenistan concerning pipeline projects for the export of Caspian Sea oil and gas to world markets via Turkey, bypassing the alternative routes across Russia and the Islamic Republic of Iran. The two agreements envisage the construction of an oil pipeline from Baku in Azerbaijan to Ceyhan in southeast Turkey, and a Transcaspian gas pipeline linking Turkmenistan with northeast Turkey via the Caspian seabed and the Caucasus Mountains. The agreements also appear to resolve a border dispute between Azerbaijan and Turkmenistan over ownership of three Caspian oilfields linked to pipeline projects.

$>\quad$ The Silk Road agreement, September 1998. All the CIS countries (excluding the Russian Federation and Turkmenistan) along with Bulgaria, Romania, and Turkey, signed the agreement which provides for coordinated development of transport links between China and Europe, and the regulation of transport tariffs and custom procedures across the region. 


\section{References}

Andriamananjara, S., and M., Schiff. 2001, "Regional Cooperation among Microstates," in Review of International Economics, Vol. 9, February 1, pp. 41-52.

Bhagwati, J., 1993, "Regionalism and Multilateralism: An Overview," in New Dimensions in Regional Integration, ed. by J. De Melo and A. Panagariya (New York: Cambridge University Press).

Elborgh-Woytek, K., 2003, "On the Openness and Distance, CIS Trade Developments, 1993-2002,” IMF Working Paper No. 03/207 (Washington: International Monetary Fund).

Francois, J., and K. Hall, 1997, "Partial Equilibrium Modeling," in Applied Methods for Trade Policy Analysis: A Handbook, edited by J. Francois and K. Reinert (London: Cambridge University Press).

Freinkman, L., E. Polyakov, and C. Revenco, 2004, "Trade Performance and Regional Integration in the CIS," ISSN 1726-5878; No. 38 (Washington, The World Bank).

Hoekman, B., F. Ng, and M. Olarreaga, 2002, "Eliminating Excessive Tariffs on Exports of Least Developed Countries," World Bank Economic Review, Vol. 15(1), pp 1-21.

Kee, H. L., A. Nicita, and M. Olarreaga, 2004, "Estimating Import Demand Elasticities," (Washington, DC: The World Bank).

Krishna, P., 1998, "Regionalism and Multilateralism: A Political Economy Approach," Quarterly Journal of Economics, Vol. 113 (No. 1, February).

Krueger, A., 1995, "Free Trade Agreements Versus Customs Unions," NBER Working Paper No. 5084 (Cambridge, MA: National Bureau of Economic Research).

Krugman, P., 1991, “Is Bilateralism Bad?” in New Dimensions in Regional Integration, ed. by J. De Melo and A. Panagariya (New York: Cambridge University Press).

__ 1993, "Regionalism versus Multilateralism: Analytical Notes, Is Bilateralism Bad?" in International Trade and Trade Policy, ed. by E. Helpman and A. Razin (Cambridge, MA: MIT Press).

Lissovolik, B., and L. Lissovolik, 2004, "Russia and the WTO: The Gravity of Outsider Status," IMF Working Paper No. 04/159 (Washington: International Monetary Fund).

Ludema, R., 1996, “On the Value of Preferential Trade Agreements in Multilateral Negotiations," available via the Internet at: http://econwpa.wustl.edu/eps/it/papers/9802/9802003.pdf. 
Michalopoulos, C., and D. Tarr, 1997, "The Economics of Customs Unions in the Commonwealth of Independent States," Post Soviet Geography and Economics, Vol. 38, No.3.

Michalopoulos, C., 2004, "The Integration of CIS-7 Countries into the World Trading System," in The Low-Income Countries of the Commonwealth of Independent States: Progress and Challenges in Transition, ed. by C. Shiells and S. Sattar (Washington: International Monetary Fund and the World Bank).

Panagariya, A., 1995, "Free Trade Area of the Americas: Good for Latina America?" in Developing and Newly Industrializing Countries, ed. by C. Milner, Volume I, (Chelentham, U.K.: Edward Elgar Publishing Limited), Chapter 17, pp. 375-405.

Roberts, M., and Wehrheim, P., 2001, "Regional Trade Agreements and WTO Accession of CIS Countries," Intereconomics, No. 6 (November-December), pp. 315-23.

Schiff, M., and A. Winters, 2003, Regional Integration and Development, The World Bank.

Shiells, C., and S. Sattar, eds., 2004, The Low-Income Countries of the Commonwealth of Independent States. Progress and Challenges in Transition (Washington, DC: International Monetary Fund and the World Bank).

Viner, J., 1950, The Custom Union Issue (New York: Carnegie Endowment for International Peace).

World Trade Organization, 2004, Annual Report (Geneva: WTO).

Yang, Y., 2003, "Strategy for Sustained Growth," in Republic of Kazakhstan, Selected Issues and Statistical Appendix, Country Report 03/211, Chapter 3 (Washington: International Monetary Fund). 